\title{
Technology in distance education: Turbo charging the horse and buggy
}

\author{
P J Smith \\ Gordon Technical College \\ President, Australian and South Pacific External Studies Association
}

\begin{abstract}
This paper argues that educationists will have to re-consider their present attitudes to education if the full potential of technology is to be realised in distance education. In particular the paper addresses the issues of structure and external studies, the needs of education and training and the need to explore the concept of open learning.
\end{abstract}

In this paper, I am not going to talk about technology very much, instead, I intend to talk more about attitudes of educators. The point I want to make is that, until we are prepared to change some of our fundamental attitudes about education, we as educators will never fully capitalise on the potential benefits of technology, and nor will we enable our students to reap all the benefits.

Let's look first at the past, in what I apologise for as something of an overly simplified summary of how education has arrived where it is. Education first began very informally, where groups of people, or even individuals, formed a relationship with a person who had something to teach them - the Socrates model. Skipping over a few hundred years we find the same sort of thing happening in the Middle Ages where the clergy, who had access to books and who could read, gathered people together and read to them. In a society with poor literacy and poor learning resources, that was a sensible learning delivery mode. In other worlds, an appropriate response.

Wardle (1974) describes the history of formal schooling in England. Starting during the industrial revolution and continuing after it, we saw the need for increased literacy and numeracy, and a greater concern for social justice. The educational response at that time was again appropriate, was an extension of the previous model and, of course, was a mass extension of the already existing church and community run schools. That response was to collect children together into school buildings and to appoint teachers. The first government run Departments of Education or Public Instruction as they were called, were formed in the second half of the nineteenth century. One of the results of that was the formation of teachers' unions and, together with management practices in education authorities, teachers' working conditions started to be defined in terms of class size and contact hours. Added to that was the need to grant holidays during the traditional summer harvest time, 
when children were required to assist on the farms; and the need to grant holidays for the religious festivals of Christmas and Easter.

Thus evolved a three term system, based on face to face instruction given to groups collected together in the one place at the same time. We still adhere to that model.

Moving on to the present, I do not intend to dwell any longer on the issues of mainstream education. Rather, I want to examine what distance educators have achieved. Armed with early printing presses and later, with the cheap and flexible technology Gestetner gave us, we developed a system based on printed materials and the postal system. That was an appropriate response. What was not an appropriate response in Australia, although we have continued to persist with it, was our translation of the lock step school year approach to scheduling and course design. We took the traditional education system and we externalised it. We based our operations on terms (or semesters), on long Christmas breaks, and on tight course structures that grouped people together in a lock-step style of instruction.

Technology has assisted us in doing that through offset printing, photocopying, audiotape and, in the past few years, videotape, teleconferencing and computer aided learning. In a society of increased literacy and increased access to learning resources that are broadcast or that are specific, that has been successful. Who can argue with success?

Distance education has been the fastest growing study mode in Australia postsecondary education for a decade now (see Figure 1) and the reasons are not hard to find:

- the quality of the educational experience has been greatly enhanced;

- there is greater community acceptance of distance education as a quality education;

- there are groups in society returning to study for different reasons, and distance education fits well with their other commitments as adults;

- distance education is congruent with the increased privacy of our society. (See Johnson, 1983, for a further analysis of the growth of distance education in Australia.)

My point here is, though, that we must not stop at using technology to translate the traditional education model into an external form. If we are going to make rapid response to education and training needs; if we are going to seriously follow access, equity and participation objectives; and if we are going to lower the unit cost of education, we need to change.

We can now use technology to escape from the traditional model and offer forms of education that:

- allow much greater learner control of what is to be learned, and how, when and where it is to be learned

- allow more rapid response to training and education needs in society;

- do not have a cost structure that is linearly related to the participation.

Packages and resources can be developed and then amortised over a large number of participants and a variable length of time. 


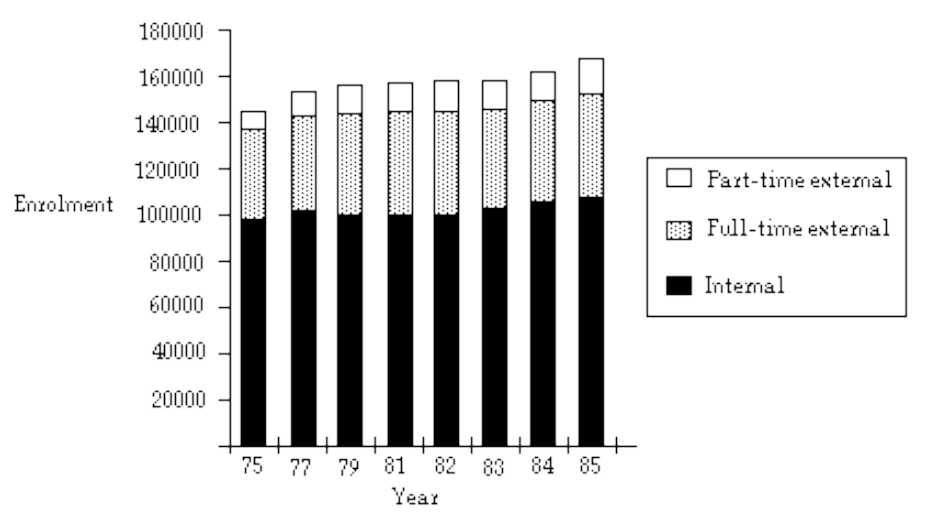

Figure 1a: Growth of enrolments by study mode University sector 1975-1985.

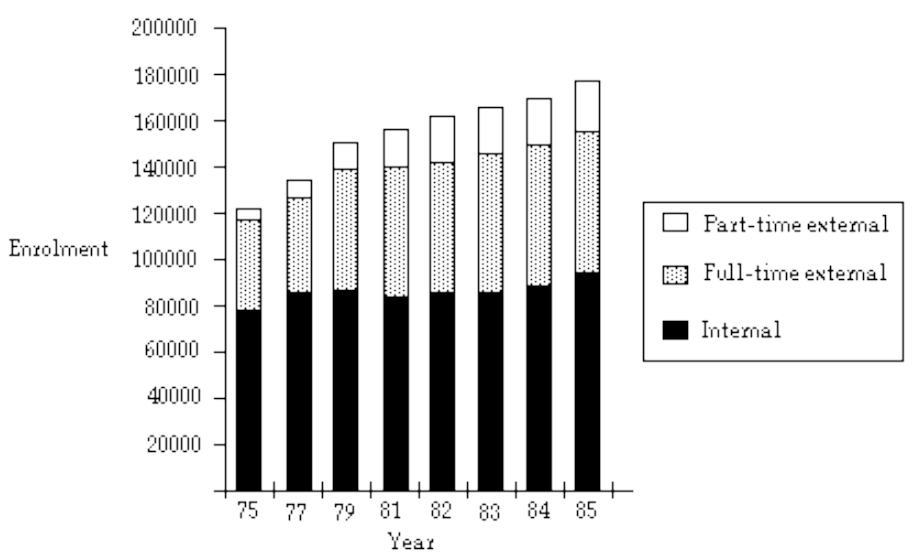

Figure 1b: Growth of enrolments by study mode CAE sector 1975-1985.

In the future, I believe that we need to take the concept of open learning (Lewis, 1986) seriously and embrace it wherever we can. We need to realise that technology as an adjunct to learning materials delivery can achieve that; that technology as the vehicle for interaction and student support can achieve that; and that technology to support the more complex enrolment registers, student recording and management systems, and financial accounting can also help us to achieve that.

I am not too bothered about the long debates we academics could enjoy defining what we mean by open learning. When I talk about open learning today I mean that which is as free as we can possibly make it of the following constraints:

- where it is learned

- how it is learned

- by whom it is learned

- what is learned

- when it is learned. 
I am certainly not advocating here that there be no constraints - clearly in many circumstances, particularly those where the learning results in an accredited award, there have to be constraints. However, I am advocating that we examine closely which constraints we place upon learning because we find the constraint convenient (eg, where, when, how), which constraints we place on learners because we cannot tolerate a situation where there are not rules in which we put our faith (eg, admission criteria that apply as blanket rules). Once we have examined those constraints, let's make them as liberal as we possibly can while at the same time maintaining integrity as professional educators. In other words, our attitude should be to make learning open and only have minimal constraints where they are necessary, rather than have constraints that we only relax when it seems convenient or respectable to do so.

Technology now can do it with our help. We only have to look at the statistics on the growth of external studies in Australia to see that. Distance education has been going from strength to strength throughout the world. Open learning has been attracting considerable interest and involvement from students and employers in Britain, through the Southtek and Northtek programs; in Canada through the Knowledge Network of the West and the Open Learning Institute; and in the United States private sector provided open education is growing rapidly. Additionally, the community is acquiring the equipment necessary for use in education.

I believe that all of these developments indicate what should by now be obvious - the community wants the greater flexibility that open learning and technology can afford. It is logical that it be so. After all, do not most of us, most of the time, learn what we want to learn, when, where and how we wish to learn it? Apart from, that is, when our learning is taking place in the context of what we call organised education.

Technology is one key to making a more appropriate response to the educational needs of the last two decades of this century. But to maximise that opportunity we need to change the ways in which we as educators, our institutions, and the various education authorities think about educational provision.

Unless we work to effect those sorts of changes we will only use technology to turbo charge the horse and buggy.

\section{References}

Johnson, R. (1983). The provision of external studies in Australian higher education. Canberra: CTEC.

Lewis, R. (1986). What is open learning? Open Learning, June, 5-10.

Wardle, D. (1974). The rise of the schooled society: The history of formal schooling in England. London: Routledge and Kegan Paul.

Based on a paper presented at EdTech'86, International Educational Technology Conference and Exhibition, University of Western Australia, Perth, 2-5 December 1986.

Please cite as: Smith, P. J. (1987). Technology in distance education: Turbo charging the horse and buggy. Australian Journal of Educational Technology, 3(1), 33-36. http: / / www.ascilite.org.au/ajet/ajet3/smith.html 